\title{
Muscle and not neuronal biomarkers correlate with severity in spinal and bulbar muscular atrophy
}

Vittoria Lombardi, PhD, Giorgia Querin, MD,* Oliver J. Ziff, MD, MRCP,* Luca Zampedri, * Ilaria Martinelli, MD, Carolin Heller, Martha Foiani, Cinzia Bertolin, PhD, Ching-Hua Lu, MD, PhD, Bilal Malik, PhD, Kezia Allen, Carlo Rinaldi, MD, PhD, Henrik Zetterberg, PhD, Amanda Heslegrave, PhD, Linda Greensmith, PhD, Michael Hanna, FRCP, Gianni Soraru, MD, PhD, Andrea Malaspina, MD, PhD, FRCP, $¥$ and Pietro Fratta, MD, PhD‡

Neurology ${ }^{\circledR}$ 2019;92:e1205-e1211. doi:10.1212/WNL.0000000000007097

\section{Abstract}

\section{Objective}

To determine whether blood biomarkers of neuronal damage (neurofilament light chain [NfL]), muscle damage (creatine kinase $[\mathrm{CK}]$ ), and muscle mass (creatinine) are altered in spinal and bulbar muscular atrophy (SBMA) and can be used as biomarkers for disease severity.

\section{Methods}

In this multicenter longitudinal prospective study, plasma and serum were collected from 2 cohorts of patients with SBMA in London, United Kingdom $(\mathrm{n}=50)$, and Padova, Italy $(\mathrm{n}=$ 43), along with disease (amyotrophic lateral sclerosis [ALS]) and healthy controls, and levels of plasma and serum NfL, CK, and creatinine were measured. Disease severity was assessed by the SBMA Functional Rating Scale and the Adult Myopathy Assessment Tool at baseline and 12 and 24 months.

\section{Results}

Blood NfL concentrations were increased in ALS samples, but were unchanged in both SBMA cohorts, were stable after 12 and 24 months, and were not correlated with clinical severity. Normal NfL levels were also found in a well-established mouse model of SBMA. Conversely, CK concentrations were significantly raised in SBMA compared with ALS samples, and were not correlated to the clinical measures. Creatinine concentrations were significantly reduced in SBMA, and strongly and significantly correlated with disease severity.

\section{Conclusions}

While muscle damage and muscle mass biomarkers are abnormal in SBMA, axonal damage markers are unchanged, highlighting the relevant primary role of skeletal muscle in disease pathogenesis. Creatinine, but not $\mathrm{CK}$, correlated with disease severity, confirming its role as a valuable biomarker in SBMA.

\author{
Correspondence \\ Dr. Fratta \\ p.fratta@ucl.ac.uk \\ or Dr. Malaspina \\ a.malaspina@qmul.ac.uk
}

\section{MORE ONLINE}

D CME Course

NPub.org/cmelist

*These authors contributed equally to this work.

¥These authors contributed equally to this work.

From the Institute of Neurology (V.L., O.J.Z., L.Z., C.H., M.F., C.-H.L., B.M., H.Z., A.H., L.G., M.H., P.F.), University College London Institute of Neurology, Queen Square, London; Blizard Institute (V.L., A.M.), Queen Mary, University of London, UK; Department of Neurosciences (G.Q., I.M., C.B., G.S.), University of Padova, Italy; Department of Neurology (C.-H.L.), China Medical University Hospital, Taiwan; Basildon Hospital (K.A.), UK; Department of Physiology, Anatomy and Genetics (C.R.), University of Oxford; UK Dementia Research Institute at UCL (H.Z., A.H.), London, UK; Clinical Neurochemistry Laboratory (H.Z.), Sahlgrenska University Hospital; and the Department of Psychiatry and Neurochemistry (H.Z.), Institute of Neuroscience and Physiology, the Sahlgrenska Academy at the University of Gothenburg, Mölndal, Sweden.

Go to Neurology.org/N for full disclosures. Funding information and disclosures deemed relevant by the authors, if any, are provided at the end of the article.

The Article Processing Charge was funded by Medical Research Council UK.

This is an open access article distributed under the terms of the Creative Commons Attribution License 4.0 (CC BY), which permits unrestricted use, distribution, and reproduction in any medium, provided the original work is properly cited. 


\section{Glossary}

ALS $=$ amyotrophic lateral sclerosis; ALSFRS $=$ Amyotrophic Lateral Sclerosis Functional Rating Scale; AMAT $=$ Adult Myopathy Assessment Tool; AR = androgen receptor; $\mathbf{C K}=$ creatine kinase; $\mathbf{K D}=$ Kennedy disease; $\mathbf{L M N}=$ lower motor neuron; NfL = neurofilament light chain; $\mathbf{P R L}=$ progression rate to last visit; $\mathbf{S B G}=$ streptavidin- $\beta$-galactosidase; $\mathbf{S B M A}=$ spinal and bulbar muscular atrophy; SBMAFRS = Spinal and Bulbar Muscular Atrophy Functional Rating Scale.

Spinal and bulbar muscular atrophy (SBMA), also known as Kennedy disease $(\mathrm{KD})$, is a disabling adult onset neuromuscular disorder that affects men and is primarily characterized by slowly progressive weakness and wasting of bulbar and limb muscles. ${ }^{1,2}$ SBMA is caused by the expansion of a CAG repeat in the androgen receptor (AR) gene and is characterized by muscle denervation and loss of lower motor neurons in the spinal cord and the brainstem. Signs of primary skeletal muscle damage, such as muscle fiber splitting, fiber degeneration, and centralized nuclei, are also present in SBMA, and recent work showing that silencing of the mutation in muscle is able to rescue the disease phenotype in disease models has further highlighted the relevance of a primary myopathic component in this disorder. ${ }^{3-9}$

No therapy is currently available for SBMA and an important limitation to trials for promising therapeutic strategies has been the lack of effective outcome measures. Biomarkers to measure disease progression and therapeutic responses are therefore strongly needed.

Neurofilament light chain (NfL) has been found to be increased in serum and plasma of numerous neurologic conditions, including amyotrophic lateral sclerosis (ALS) and inherited peripheral neuropathies, and to be a promising tool to monitor disease progression. ${ }^{10,11}$ We here use the currently most sensitive methodology to measure NfL in patients with SBMA and in a rodent model of disease, ${ }^{12}$ and compare this marker of neuronal damage with measures of muscle damage and loss.

\section{Methods}

\section{Standard protocol approvals, registrations, and patient consents}

Plasma and serum were prospectively collected with informed consent from 2 cohorts of patients with a genetically confirmed diagnosis of SBMA attending the $\mathrm{KD}$ clinic at the National Hospital for Neurology in London, United Kingdom $(\mathrm{n}=50)$, and at the University Hospital in Padova, Italy ( $\mathrm{n}=$ 43). Samples from patients with ALS $(\mathrm{n}=53)$ and healthy relatives of patients $(n=73)$ were collected in neuromuscular clinics in the same centers.

Approvals were obtained from the East London and the City Research Ethics Committee (09/H0703/27). Written informed consent was obtained from all participants in the study.

\section{Patient evaluation}

All patients were recruited in neuromuscular clinics at the National Hospital for Neurology in London, United Kingdom, and at the University Hospital in Padova, Italy. All participants with SBMA carried a pathogenic expansion of the CAG trinucleotide repeat ( $>38$ repeats) in the AR gene. ALS cases all were recruited according to El Escorial probable and definite ALS criteria. Controls were recruited in both centers in order to reduce sources of bias. Healthy controls were excluded if they had coexistent neurologic disease as determined by a symptom and medical history-based questionnaire.

SBMA and ALS disease severity and progression were evaluated using functional rating scale scores (Spinal and Bulbar Muscular Atrophy Functional Rating Scale [SBMAFRS], Amyotrophic Lateral Sclerosis Functional Rating Scale [ALSFRS]), and patients with SBMA were further evaluated with the Adult Myopathy Assessment Tool (AMAT). ${ }^{13-15}$

Progression rate in patients with ALS was calculated as progression rate to last visit (PRL). This was the ALSFRS-revised (range 1-48, with lower scores corresponding to higher level of neurologic impairment) approximated to 48 at onset minus the score at last visit divided per disease duration expressed in month $($ ALS-Fast $=$ PRL $>1$; ALS-Slow $=$ PRL $<0.5$ ).

\section{Sample collection and processing}

Samples were processed, stored, and analyzed as previously described. ${ }^{10,11}$ Blood samples from all participants were collected into EDTA-containing tubes and centrifuged at $20^{\circ} \mathrm{C}$ at 3,500 rpm for 10 minutes within 1 hour. Repeat samples were taken after 1 and 2 years, when available. Plasma and serum were aliquoted and stored at $-80^{\circ} \mathrm{C}$.

\section{Mouse samples}

All experimental procedures were carried out under license from the UK Home Office (Scientific Procedures Act 1986), and following approval by the Ethical Review Panel of UCL Institute of Neurology. Yeast artificial chromosome (YAC) AR100 mice, which express at endogenous levels the human androgen receptor with an expanded CAG repeat, ${ }^{12}$ were bred and maintained at UCL Institute of Neurology Biological Services. Heterozygote males carrying the androgen receptor with 100 polyglutamine repeats (pathogenic AR100 mice) were mated with wild-type C57BL/6J females. Only male mice were used in this study and male age-matched wild-type littermates were used as controls. Mouse plasma was obtained from male AR100 mice and controls at 18 months of age, as previously described. ${ }^{12,16}$ 
The quantitative determination of NfL in human plasma (UK cohort) and serum (Italian cohort) was undertaken by single molecule array (Simoa) technology using a digital immunoassay Simoa HD-1 Analyzer (Quanterix; Lexington, MA) using a commercially available NfL kit from the same vendor. Plasma samples from KD, ALS-Fast, ALS-Slow, and healthy patients, along with $\mathrm{KD} / \mathrm{WT}$ mice, were equally distributed on each plate and measured in duplicate. Each plate contained a target-specific calibrator $(500-0.686 \mathrm{pg} / \mathrm{mL})$ and 2 quality controls (10 and $200 \mathrm{pg} / \mathrm{mL}$ ).

In the first step, anti-NfL-antibody-coated paramagnetic capture beads, sample, and biotinylated detector antibody are combined. NfL molecules present in the sample are captured by the anti-NfL-antibody-coated capture beads and labeled with biotinylated detector antibodies. After washing, a conjugate of streptavidin- $\beta$-galactosidase (SBG) is mixed with the capture beads. SBG binds to the biotinylated detector antibodies, resulting in enzyme labeling of captured NfL. CK and creatinine were measured as part of routine clinical testing.

\section{Statistical analysis}

Statistical analysis was performed using GraphPad Prism 5.0 (GraphPad; La Jolla, CA). Patient NfL, CK, and creatinine concentrations were compared using analysis of variance and Bonferroni correction for multiple testing. Mouse NfL levels were compared using Mann-Whitney test. Correlations of CK and creatinine levels with SBMAFRS and AMAT scores were assessed using Spearman correlation coefficients. We included all available samples for this study, given the rarity of the disease and the unknown variability and changes of NfL in SBMA prior to this work. Missing data were omitted from analysis-all numbers for each analysis are reported in the table.

\section{Data availability}

Anonymized data not published within this article will be made available by request from any qualified investigator.

\section{Results}

\section{Cohorts}

The study included 93 patients with SBMA, 53 patients with ALS, and 73 healthy controls. Participant characteristics are summarized in the table.

\section{NfL levels are unchanged in 2 cohorts of patients with SBMA}

We measured the plasma levels of NfL, using the highly sensitive Simoa assay, in samples from the UK SBMA cohort, and compared them with healthy controls and with slow and fast progressor ALS cases, as positive controls. While fast and slow ALS progressors showed the previously described ${ }^{11}$ increase in NfL levels ( $p<0.0001$ and $p=0.0008$, respectively), we detected no significant increase in the SBMA cases $(p=$ 0.99). This finding was replicated in the Italian SBMA cohort 
$(p>0.99)$ (figure 1A). We further examined whether levels changed longitudinally at $12(n=28)$ and $24(n=8)$ months, and showed NfL levels to be stable across this time, with the exception of $3 / 28$ cases where levels increased to $>58 \mathrm{pg} / \mathrm{mL}$, the 95th percentile of controls (figure 1B).

\section{$\mathrm{NfL}$ levels are unchanged in a mouse model of disease}

We assessed NfL levels in a well-established SBMA mouse model: AR100 mice. These mice express a 100-CAG expansion in the human $\mathrm{AR}$ and develop a late-onset progressive neuromuscular phenotype characterized by muscle atrophy and motor neuron degeneration, with no motor neuron loss at 6 months, and a $40 \%$ loss of motor neurons at 18 months of age (B. Malik and L. Greensmith, personal written communication, July 30, 2018, and references 12 and 17). NfL measurements performed on the same platform as for the human samples did not show a significant increase in AR100 mice at 18 months vs littermate controls $(\mathrm{n}=9 ; p=0.45)$ (figure 1C).

NfL levels are not increased in blood-derived biofluids from 2 independent SBMA cohorts and a well-established mouse model of disease.

\section{Muscle damage and muscle mass markers are significantly altered in SBMA}

We investigated the levels of markers of muscle damage (CK) and muscle mass (creatinine) in our patient cohorts using standard clinical diagnostic assays. CK levels showed remarkably similar values in both the UK and Italian cohorts (mean 951 and $940 \mathrm{U} / \mathrm{L}$, respectively), and were significantly increased compared to both healthy controls (mean $122 \mathrm{U} / \mathrm{L}, p<0.0001$ for both UK and Italian cohorts) and ALS $(p<0.0001$ for both UK and Italian cohorts vs slow and fast progressing ALS). Interestingly, CK levels, differently from $\mathrm{NfL}$, did not differ between slow and fast progressing ALS (mean 699 and $701 \mathrm{U} / \mathrm{L}$, respectively, $p>0.99$ ) (figure 2A).
Creatinine levels were very similar in UK and Italian cohorts and significantly decreased compared to controls and ALS (figure 2C).

\section{Creatinine levels correlate with SBMA severity}

To evaluate disease severity, we used the SBMAFRS, a function rating scale developed for SBMA, and the AMAT score, which detects deficits in functional muscle performance and endurance and has been used as an outcome measure for SBMA clinical trials. ${ }^{13-15}$ While no significant correlation was present between clinical measures and CK (figure 2B), creatinine levels strongly inversely correlated with both SBMAFRS and AMAT in both SBMA cohorts (figure 2D).

\section{Discussion}

We show that NfL concentration in blood is unchanged in patients with SBMA compared with controls, and concentrations do not change over time and are not related to disease severity. The result was confirmed in a well-established mouse model of SBMA. This is surprising given that NfL has been described to be increased in numerous neurodegenerative conditions and mouse models, and cannot simply be imputed solely to the slowly progressive nature of SBMA, as a recent study using the same technique has detected an NfL increase in Charcot-Marie-Tooth disease, another very slowly progressive neuromuscular condition. ${ }^{10,11,16,18,19}$

Conversely, markers of muscle damage ( $\mathrm{CK}$ ) and muscle mass (creatinine) are aberrant in SBMA. CK is elevated compared to both controls and ALS cases, and does not correlate to clinical measures, possibly due to its reflection of more acute muscle damage, whereas creatinine is reduced and significantly correlates with disease severity. A decrease in creatinine has also been shown in a Japanese SBMA cohort to correlate with grip strength and 6-minute walk distance and has also been shown

Figure 1 Neurofilament light chain (NfL) levels are unchanged in spinal and bulbar muscular atrophy (SBMA)
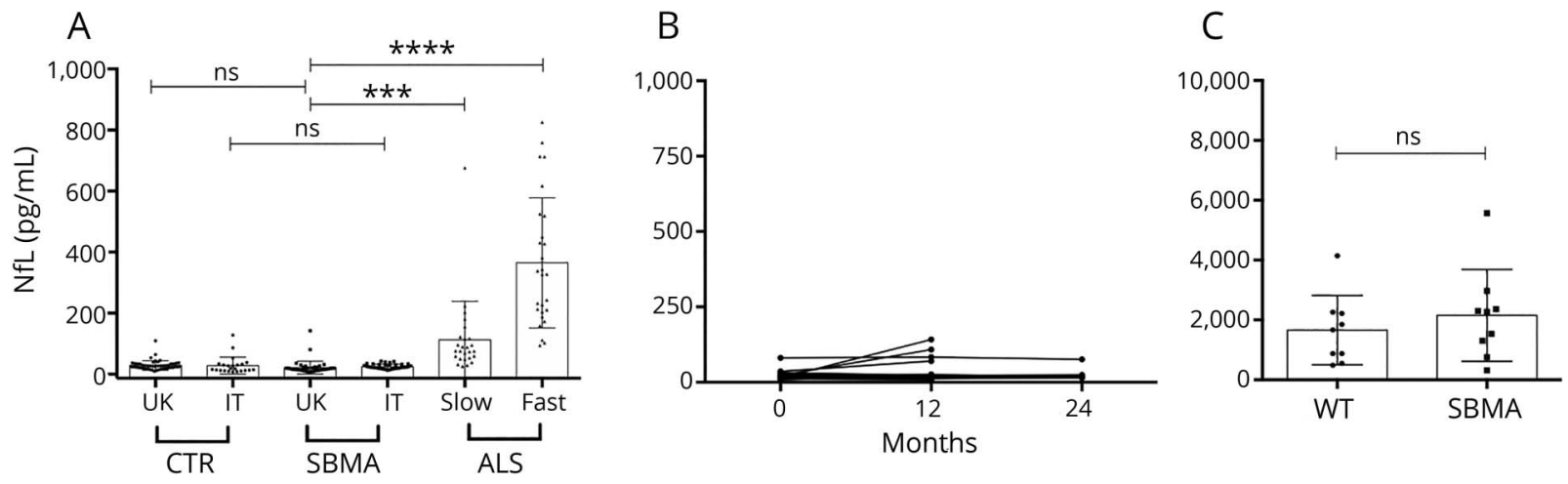

(A) NfL concentrations ( $\mathrm{pg} / \mathrm{mL}$ ) from the UK cohort (plasma, UK control [CTR], UK SBMA, slow amyotrophic lateral sclerosis [ALS], and fast ALS) and the Italian cohort (IT CTR and IT SBMA). Assays were conducted together, but statistical analysis (analysis of variance, Bonferroni multiple comparison correction) is represented only between samples from the same cohort. (B) NfL concentrations in the longitudinal study in the UK cohort. Twelve-month ( $\mathrm{n}=28$ ) and 24month ( $n=8$ ) timepoints represent $12 \pm 2$ and $24 \pm 2$ months. (C) NfL levels from AR100 (SBMA) and littermate control (WT) mice are shown (Mann-Whitney

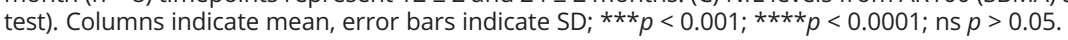


Figure 2 Creatine kinase (CK) and creatinine levels are altered in spinal and bulbar muscular atrophy (SBMA) and correlate with clinical severity
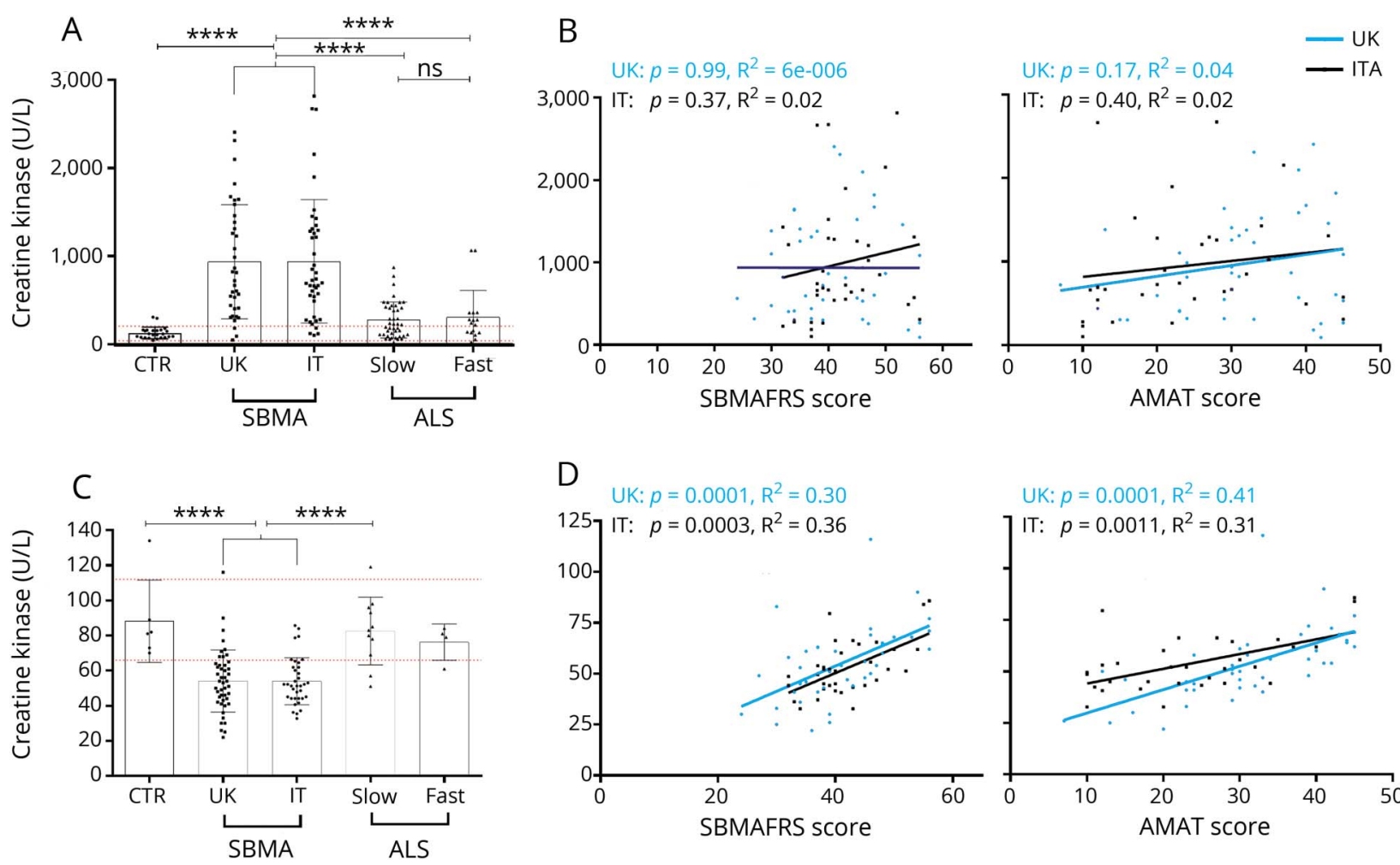

\section{D}
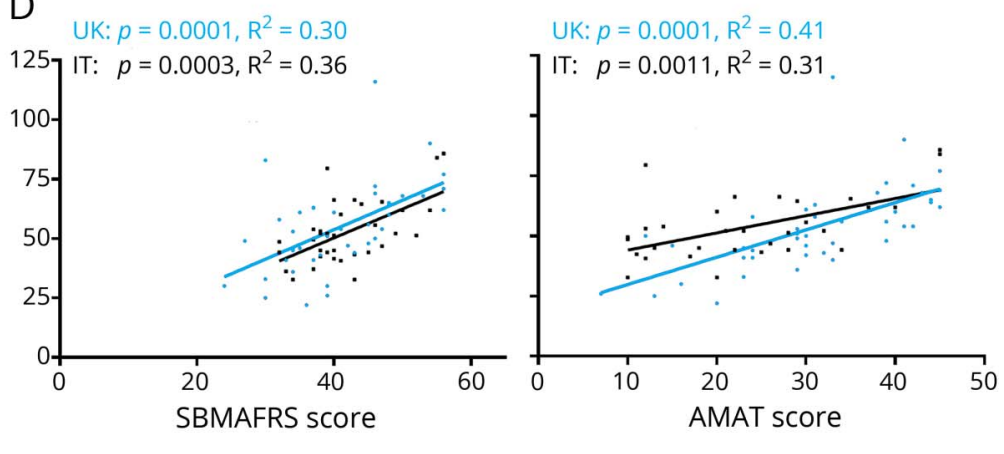

(A) CK SBMA plasma concentrations from both UK and Italian cohorts are significantly increased compared to controls (CTR) $(p<0.0001)$ and slow ( $p<0.0001)$ and fast ( $p=0.0003$, United Kingdom; $p=0.0002$, Italy) progressive amyotrophic lateral sclerosis (ALS). (B) CK concentrations of both UK and Italian cohorts do not significantly correlate with the Spinal and Bulbar Muscular Atrophy Functional Rating Scale (SBMAFRS) (left) and Adult Myopathy Assessment Tool (AMAT) (right) clinical severity scores (for SBMAFRS: United Kingdom, $r=-0.02, p=0.99$; Italian, $r=0.25, p=0.15$; and for AMAT: United Kingdom, $r=0.15, p=0.32 ;$ IT, $r=$ $0.29, p=0.11$ ). (C) Creatinine plasma concentrations from both UK and Italian cohorts are significantly decreased compared to controls ( $p<0.0001)$ and slow progressive ALS $(p<0.0001)$. (D) Creatinine concentrations of both UK and Italian cohorts significantly correlate with the SBMAFRS (left) and AMAT (right) clinical severity scores (for SBMAFRS: United Kingdom, $r=0.61, p<0.0001$; Italy, $r=0.49, p=0.0035$; and for AMAT: United Kingdom, $r=0.75, p<0.0001$; Italy, $r=$ $0.50, p=0.0044$ ). Blue (United Kingdom) and black (Italy) lines represent the best-fit line. Red dashed lines represent upper and lower extremities of the normal range. Columns indicate mean, error bars indicate SD; $* \star \star * p<0.0001 ;$ ns $p>0.05$.

to be lower in patients with SBMA than in patients with ALS who have comparable wasting of muscle mass. ${ }^{20,21}$

Traditionally SBMA has been considered a lower motor neuron (LMN) disease. Indeed, denervation is a crucial neurophysiology finding, and loss of LMN in postmortem tissue has been well-documented. ${ }^{2,22}$ Muscle abnormalities and CK levels elevated beyond those found in ALS have been described in early case series of this disease. ${ }^{23}$ Nonetheless, only recently, analysis of SBMA muscle biopsies, and functional work specifically exploring the role of muscle in mouse models, have led to acknowledging a primary muscle component to be relevant for disease progression and pathogenesis alongside the neurogenic component, ${ }^{3-9}$ and our findings support this.

Finally, SBMA and ALS are in differential diagnosis, and a substantial proportion of patients with SBMA initially receive a diagnosis of ALS, causing distress. ${ }^{24}$ Although genetic clinical testing is the gold standard for SBMA diagnosis, the finding of normal levels of NfL in SBMA could be used in a diagnostic panel of biochemical markers to help differentiate patients presenting with motor neuron deficits.
NfL concentrations in blood were unchanged in 2 cohorts of patients with SBMA and in a mouse model of disease, while markers of muscle damage and mass were altered, the latter showing correlation with clinical measures of disease, suggesting that biomarkers of muscle damage and mass, rather than neuronal damage, should be used to monitor disease progression and outcome. This is consistent with previous observations that a primary myopathic component plays a primary role in the disorder ${ }^{3-9}$ and supports the development of novel disease-modifying agents towards the muscle target and the incorporation of muscle biomarkers to objectively assess outcomes in therapeutic trials in SBMA.

\section{Acknowledgment}

The authors thank the patients involved in the study and their families for participation in and support of $\mathrm{KD}$ research.

\section{Study funding}

P.F. is supported by an MRC/MNDA LEW Clinician Scientist Fellowship (MR/M008606/1) and the NIHR UCLH Biomedical Research Centre. This study was supported by the NIHR UCLH Biomedical Research Centre, the UCL 
Kennedy's Disease Fund, and KDUK. O.J.Z. is funded by the UK National Institute of Health Research on an Academic Clinical Fellowship. G.S. is supported by Grant Telethon GTB12001D (Telethon Biobank ed EuroBiobank), Telethon GUP15009B, and AFM-Telethon grant number 18722. C.R. is funded by a Wellcome Trust Clinical Research Career Development Fellowship and the Muscular Dystrophy Association (MDA). H.Z. is funded by the UK Dementia Research Institute at UCL, the European Research Council, the Swedish Research Council, and the Knut and Alice Wallenberg Foundation. The Simoa instrument was bought using a Wellcome Trust multi-user equipment grant (PI: H.Z.). Study Funded by the NIHR UCLH Biomedical Research Centre Grant \#BRC279566.

\section{Disclosure}

The authors report no disclosures relevant to the manuscript. Go to Neurology.org/N for full disclosures.

\section{Publication history}

Received by Neurology August 12, 2018. Accepted in final form November 5, 2018.

\begin{tabular}{|c|c|c|c|}
\hline Name & Location & Role & Contribution \\
\hline $\begin{array}{l}\text { Vittoria } \\
\text { Lombardi, } \\
\text { PhD }\end{array}$ & $\begin{array}{l}\text { Blizard Institute, } \\
\text { Queen Mary, } \\
\text { University of London, } \\
\text { UK }\end{array}$ & Author & $\begin{array}{l}\text { Data acquisition and } \\
\text { data analysis, } \\
\text { statistical analysis, } \\
\text { writing of the } \\
\text { manuscript }\end{array}$ \\
\hline $\begin{array}{l}\text { Giorgia } \\
\text { Querin, MD }\end{array}$ & $\begin{array}{l}\text { Department of } \\
\text { Neurosciences, } \\
\text { University of Padova, } \\
\text { Italy }\end{array}$ & Author & $\begin{array}{l}\text { Data acquisition and } \\
\text { data analysis }\end{array}$ \\
\hline $\begin{array}{l}\text { Luca } \\
\text { Zampedri }\end{array}$ & $\begin{array}{l}\text { Institute of } \\
\text { Neurology, University } \\
\text { College London, UK }\end{array}$ & Author & $\begin{array}{l}\text { Data acquisition and } \\
\text { data analysis }\end{array}$ \\
\hline $\begin{array}{l}\text { Oliver J. Ziff, } \\
\text { MD, MRCP }\end{array}$ & $\begin{array}{l}\text { Institute of } \\
\text { Neurology, University } \\
\text { College London, UK }\end{array}$ & Author & $\begin{array}{l}\text { Statistical analysis, } \\
\text { writing of the } \\
\text { manuscript }\end{array}$ \\
\hline $\begin{array}{l}\text { Caroline } \\
\text { Heller }\end{array}$ & $\begin{array}{l}\text { Institute of } \\
\text { Neurology, University } \\
\text { College London, UK }\end{array}$ & Author & $\begin{array}{l}\text { Data acquisition and } \\
\text { data analysis }\end{array}$ \\
\hline $\begin{array}{l}\text { Martha } \\
\text { Foiani }\end{array}$ & $\begin{array}{l}\text { Institute of } \\
\text { Neurology, University } \\
\text { College London, UK }\end{array}$ & Author & $\begin{array}{l}\text { Data acquisition and } \\
\text { data analysis }\end{array}$ \\
\hline $\begin{array}{l}\text { llaria } \\
\text { Martinelli, } \\
\text { MD }\end{array}$ & $\begin{array}{l}\text { Department of } \\
\text { Neurosciences, } \\
\text { University of Padova, } \\
\text { Italy }\end{array}$ & Author & $\begin{array}{l}\text { Data acquisition and } \\
\text { data analysis }\end{array}$ \\
\hline $\begin{array}{l}\text { Cinzia } \\
\text { Bertolin, } \\
\text { PhD }\end{array}$ & $\begin{array}{l}\text { Department of } \\
\text { Neurosciences, } \\
\text { University of Padova, } \\
\text { Italy }\end{array}$ & Author & $\begin{array}{l}\text { Data acquisition and } \\
\text { data analysis }\end{array}$ \\
\hline $\begin{array}{l}\text { Ching-Hua } \\
\text { Lu, MD, PhD }\end{array}$ & $\begin{array}{l}\text { Department of } \\
\text { Neurology, China } \\
\text { Medical University } \\
\text { Hospital, Taichung } \\
\text { City, Taiwan }\end{array}$ & Author & $\begin{array}{l}\text { Data acquisition and } \\
\text { data analysis }\end{array}$ \\
\hline
\end{tabular}

\begin{tabular}{|c|c|c|c|}
\hline Name & Location & Role & Contribution \\
\hline $\begin{array}{l}\text { Bilal Malik, } \\
\text { PhD }\end{array}$ & $\begin{array}{l}\text { Institute of } \\
\text { Neurology, University } \\
\text { College London, UK }\end{array}$ & Author & $\begin{array}{l}\text { Data acquisition and } \\
\text { data analysis }\end{array}$ \\
\hline Kezia Allen & Basildon Hospital, UK & Author & $\begin{array}{l}\text { Data acquisition and } \\
\text { data analysis }\end{array}$ \\
\hline $\begin{array}{l}\text { Carlo } \\
\text { Rinaldi, MD, } \\
\text { PhD }\end{array}$ & $\begin{array}{l}\text { University of Oxford, } \\
\text { UK }\end{array}$ & Author & $\begin{array}{l}\text { Data acquisition and } \\
\text { data analysis, critical } \\
\text { revision of the } \\
\text { manuscript }\end{array}$ \\
\hline $\begin{array}{l}\text { Linda } \\
\text { Greensmith, } \\
\text { PhD }\end{array}$ & $\begin{array}{l}\text { Institute of } \\
\text { Neurology, University } \\
\text { College London, UK }\end{array}$ & Author & $\begin{array}{l}\text { Critical revision of } \\
\text { the manuscript }\end{array}$ \\
\hline $\begin{array}{l}\text { Henrik } \\
\text { Zetterberg, } \\
\text { PhD }\end{array}$ & $\begin{array}{l}\text { Institute of } \\
\text { Neurology, University } \\
\text { College London, UK }\end{array}$ & Author & $\begin{array}{l}\text { Critical revision of } \\
\text { the manuscript }\end{array}$ \\
\hline $\begin{array}{l}\text { Amanda } \\
\text { Heslegrave, } \\
\text { PhD }\end{array}$ & $\begin{array}{l}\text { Institute of } \\
\text { Neurology, University } \\
\text { College London, UK }\end{array}$ & Author & $\begin{array}{l}\text { Data acquisition and } \\
\text { data analysis, critical } \\
\text { revision of the } \\
\text { manuscript }\end{array}$ \\
\hline $\begin{array}{l}\text { Linda } \\
\text { Greensmith, } \\
\text { PhD }\end{array}$ & $\begin{array}{l}\text { Institute of } \\
\text { Neurology, University } \\
\text { College London, UK }\end{array}$ & Author & $\begin{array}{l}\text { Critical revision of } \\
\text { the manuscript }\end{array}$ \\
\hline $\begin{array}{l}\text { Michael } \\
\text { Hanna, FRCP }\end{array}$ & $\begin{array}{l}\text { Institute of } \\
\text { Neurology, University } \\
\text { College London, UK }\end{array}$ & Author & $\begin{array}{l}\text { Critical revision of } \\
\text { the manuscript }\end{array}$ \\
\hline $\begin{array}{l}\text { Gianni } \\
\text { Soraru, MD, } \\
\text { PhD }\end{array}$ & $\begin{array}{l}\text { Department of } \\
\text { Neurosciences, } \\
\text { University of Padova, } \\
\text { Italy }\end{array}$ & Author & $\begin{array}{l}\text { Data acquisition and } \\
\text { data analysis, critical } \\
\text { revision of the } \\
\text { manuscript }\end{array}$ \\
\hline $\begin{array}{l}\text { Andrea } \\
\text { Malaspina, } \\
\text { MD, PhD }\end{array}$ & $\begin{array}{l}\text { Blizard Institute, } \\
\text { Queen Mary, } \\
\text { University of London, } \\
\text { UK }\end{array}$ & Author & $\begin{array}{l}\text { Designed and } \\
\text { conceptualized } \\
\text { study, data } \\
\text { acquisition and data } \\
\text { analysis, critical } \\
\text { revision of the } \\
\text { manuscript }\end{array}$ \\
\hline $\begin{array}{l}\text { Pietro } \\
\text { Fratta, MD, } \\
\text { PhD }\end{array}$ & $\begin{array}{l}\text { Institute of } \\
\text { Neurology, University } \\
\text { College London, UK }\end{array}$ & Author & $\begin{array}{l}\text { Designed and } \\
\text { conceptualized } \\
\text { study, data } \\
\text { acquisition and data } \\
\text { analysis, statistical } \\
\text { analysis, writing of } \\
\text { the manuscript }\end{array}$ \\
\hline
\end{tabular}

\section{References}

1. Cortes CJ, La Spada AR. X-linked spinal and bulbar muscular atrophy: from clinical genetic features and molecular pathology to mechanisms underlying disease toxicity. Adv Exp Med Biol 2018;1049:103-133.

2. Kennedy WR, Alter M, Sung JH. Progressive proximal spinal and bulbar muscular atrophy of late onset: a sex-linked recessive trait. Neurology 1968;18:671-680.

3. Cortes CJ, Ling SC, Guo LT, et al. Muscle expression of mutant androgen receptor accounts for systemic and motor neuron disease phenotypes in spinal and bulbar muscular atrophy. Neuron 2014;82:295-307.

4. Giorgetti E, Yu Z, Chua JP, et al. Rescue of metabolic alterations in AR113Q skeletal muscle by peripheral androgen receptor gene silencing. Cell Rep 2016;17:125-136.

5. Johansen JA, Yu Z, Mo K, et al. Recovery of function in a myogenic mouse model of spinal bulbar muscular atrophy. Neurobiol Dis 2009;34:113-120.

6. Sorarù G, D'Ascenzo $\mathrm{C}$, Polo $\mathrm{A}$, et al. Spinal and bulbar muscular atrophy: skeletal muscle pathology in male patients and heterozygous females. J Neurol Sci 2008;264:100-105.

7. Malena A, Pennuto M, Tezze C, et al. Androgen-dependent impairment of myogenesis in spinal and bulbar muscular atrophy. Acta Neuropathol 2013;126:109-121.

8. Monks DA, Johansen JA, Mo K, et al. Overexpression of wild-type androgen receptor in muscle recapitulates polyglutamine disease. Proc Natl Acad Sci USA 2007;104: $18259-18264$.

9. Chahin N, Sorenson EJ. Serum creatine kinase levels in spinobulbar muscular atrophy and amyotrophic lateral sclerosis. Muscle Nerve 2009;40:126-129. 
10. Sandelius $\AA$, Zetterberg H, Blennow K, et al. Plasma neurofilament light chain concentration in the inherited peripheral neuropathies. Neurology 2018;90:e518-e524.

11. Lu C-H, Macdonald-Wallis C, Gray E, et al. Neurofilament light chain: a prognostic biomarker in amyotrophic lateral sclerosis. Neurology 2015;84:2247-2257.

12. Sopher BL, Thomas PS, LaFevre-Bernt MA, et al. Androgen receptor YAC transgenic mice recapitulate SBMA motor neuronopathy and implicate VEGF164 in the motor neuron degeneration. Neuron 2004;41:687-699.

13. Harris-Love MO, Fernandez-Rhodes L, Joe G, et al. Assessing function and endurance in adults with spinal and bulbar muscular atrophy: validity of the adult myopathy assessment tool. Rehabil Res Pract 2014;2014:873872.

14. Querin G, DaRe E, Martinelli I, et al. Validation of the Italian version of the SBMA Functional Rating Scale as outcome measure. Neurol Sci 2016;37:1815-1821.

15. Hashizume A, Katsuno M, Suzuki K, et al. A functional scale for spinal and bulbar muscular atrophy: cross-sectional and longitudinal study. Neuromuscul Disord 2015; 25:554-562.

16. Lu CH, Petzold A, Kalmar B, Dick J, Malaspina A, Greensmith L. Plasma neurofilament heavy chain levels correlate to markers of late stage disease progression and treatment response in SOD1(G93A) mice that model ALS. PLoS One 2012;7: e40998.
17. Malik B, Nirmalananthan N, Bilsland LG, et al. Absence of disturbed axonal transport in spinal and bulbar muscular atrophy. Hum Mol Genet 2011;20:1776-1786.

18. Rohrer JD, Woollacott IOC, Dick KM, et al. Serum neurofilament light chain protein is a measure of disease intensity in frontotemporal dementia. Neurology 2016;87:1329-1336.

19. Bacioglu M, Maia LF, Preische O, et al. Neurofilament light chain in blood and CSF as marker of disease progression in mouse models and in neurodegenerative diseases. Neuron 2016;91:56-66.

20. Hijikata Y, Katsuno M, Suzuki K, et al. Impaired muscle uptake of creatine in spinal and bulbar muscular atrophy. Ann Clin Transl Neurol 2016;3:537-546.

21. Hashizume A, Katsuno M, Banno H, et al. Longitudinal changes of outcome measures in spinal and bulbar muscular atrophy. Brain 2012;135:2838-2848.

22. Ogata A, Matsuura T, Tashiro K, et al. Expression of androgen receptor in X-linked spinal and bulbar muscular atrophy and amyotrophic lateral sclerosis. J Neurol Neurosurg Psychiatry 1994;57:1274-1275.

23. Harding AE, Thomas PK, Baraitser M, Bradbury PG, Morgan-Hughes JA, Ponsford JR. X-linked recessive bulbospinal neuronopathy: a report of ten cases. J Neurol Neurosurg Psychiatry 1982;45:1012-1019.

24. Fratta P, Nirmalananthan N, Masset L, et al. Correlation of clinical and molecular features in spinal bulbar muscular atrophy. Neurology 2014;82:2077-2084. 


\section{Neurology}

\section{Muscle and not neuronal biomarkers correlate with severity in spinal and bulbar muscular atrophy \\ Vittoria Lombardi, Giorgia Querin, Oliver J. Ziff, et al.}

Neurology 2019;92;e1205-e1211 Published Online before print February 20, 2019

DOI 10.1212/WNL.0000000000007097

This information is current as of February 20, 2019

$\begin{array}{ll}\begin{array}{l}\text { Updated Information \& } \\ \text { Services }\end{array} & \begin{array}{l}\text { including high resolution figures, can be found at: } \\ \text { http://n.neurology.org/content/92/11/e1205.full }\end{array} \\ \text { References } & \text { This article cites } 24 \text { articles, } 8 \text { of which you can access for free at: } \\ & \text { http://n.neurology.org/content/92/11/e1205.full\#ref-list-1 } \\ \text { This article, along with others on similar topics, appears in the } & \text { following collection(s): } \\ \text { Anterior nerve cell disease } & \text { http://n.neurology.org/cgi/collection/anterior_nerve_cell_disease } \\ & \begin{array}{l}\text { Information about reproducing this article in parts (figures,tables) or in } \\ \text { its entirety can be found online at: }\end{array} \\ & \text { http://www.neurology.org/about/about_the_journal\#permissions } \\ & \text { Information about ordering reprints can be found online: } \\ & \text { http://n.neurology.org/subscribers/advertise }\end{array}$

Neurology $\AA^{\circledR}$ is the official journal of the American Academy of Neurology. Published continuously since 1951, it is now a weekly with 48 issues per year. Copyright Copyright (C) 2019 The Author(s). Published by Wolters Kluwer Health, Inc. on behalf of the American Academy of Neurology.. All rights reserved. Print ISSN: 0028-3878. Online ISSN: 1526-632X.

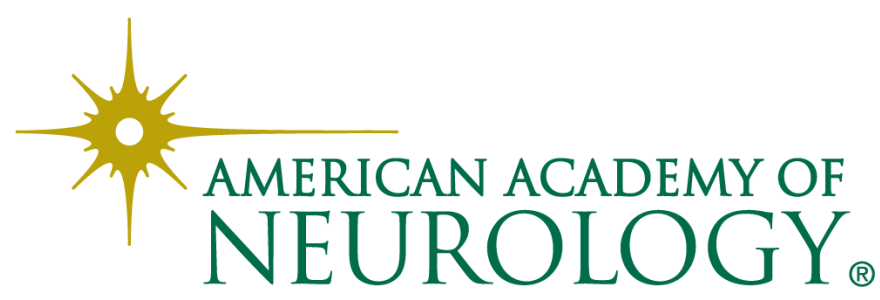

